\section{ECONOMICS}

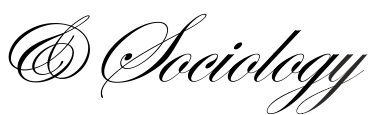

Cera, G., Belas, J., Rozsa, Z., \& Cepel, M. (2019). Linking firm characteristics to perceived important social factors for entrepreneurial activity. Economics and Sociology, 12(4), 101-115. doi:10.14254/2071-789X.2019/12-4/6

\title{
LINKING FIRM CHARACTERISTICS TO PERCEIVED IMPORTANT SOCIAL FACTORS FOR ENTREPRENEURIAL ACTIVITY
}

\author{
Gentjan Çera, \\ Tomas Bata University in Zlin, \\ Zlin, Czech Republic \\ E-mail:cera@utb.cz. \\ Jaroslav Belas, \\ Tomas Bata University in Zlin, \\ Zlin, Crech Republic \\ E-mail:belas111@gmail.com

\section{Zoltan Rozsa, \\ Alexander Dubcek. University in \\ Trencin, \\ Trencin, Slovak Republic \\ E-mail:2oltan.rozsa@tnuni.sk} \\ Martin Cepel, \\ Pan-European University, \\ Bratislava, Slovak Republic \\ E-mail: \\ martin.cepel@paneurouni.com
}

Received: January, 2019

1st Revision: September, 2019

Accepted: November, 2019

DOI: $10.14254 / 2071-$

789X.2019/12-4/6

JEL Classification:A13, L26, $\mathrm{O} 17$

\section{Introduction}

Entrepreneurship is widely acknowledged as an engine of economy, as it contributes directly to employment rate and economic growth (Abdesselam et al., 2018; Acs et al., 2018; Bosma et al. 2018). Indeed, small and medium-sized enterprises (SMEs) are vital for the European Union economies, as they generate $56.8 \%$ of the value added and employ $66.4 \%$ of the working force (European Commission, 2018). In comparison to the EU average, value
ABSTRACT. This study seeks to investigate the linkages between firm characteristics (firm age and size) and perceived important social factors for entrepreneurship. The research is administered on a firm-level data collection through a survey. The paper uses principal component analysis and non-parametric methods, including a post-hoc test to examine the above linkages within an original dataset of 641 small and medium-sized enterprises (SMEs) operating in Czech Republic and Slovakia. The results reveal that the perceived important social factors have a negative association with firm age and a positive one with firm size. Therefore, younger firms are more vulnerable to these factors as compared with their older counterparts. However, larger firms demonstrated perceived higher social factors, as compared with smaller ones. This research contributes to enriching literature by providing insights on the associations of firm characteristics and social factors for entrepreneurship in Central European context. Understanding factors which shape entrepreneurship within SME sector allows adjusting and designing policies aiming to boost entrepreneurship for certain groups of firms.
Keywords: entrepreneurship, SME, firm age, firm size, social factors, institutions, Central Europe 
added originating from SMEs in Czech Republic and Slovakia is just a bit lower. On the other hand, in terms of SMEs' contribution to employment, it is reported to be one or two per cent higher in these two countries than the EU average. According to the projections of the European Commission (2018), during the last three years (since 2017), SME value added is expected to increase by $17.2 \%$ in Slovakia and by $15.7 \%$ in Czech Republic. In terms of employment, an increase of $0.4 \%$ is predicted for Czech Republic and $4.4 \%$ for Slovakia.

The above figures indicate the importance of SMEs for economies overall. Therefore, from the perspective of academicians, public-policy advocates and governments, it is a permanent interest to better understand the factors which can enhance entrepreneurship. In this context, we feel the necessity to investigate the relationship between firm characteristics and important social factors for entrepreneurial activity to adjust policies or design new ones aiming at boosting entrepreneurship.

Researchers have demonstrated that different factors originated from within and outside organizations influence their entrepreneurial activity (Shepherd et al., 2019; Rogalska, 2018). Institutional environment is seen as a critical component in understanding the level of entrepreneurial activity (Bjørnskov \& Foss, 2016; Bowen \& De Clercq, 2008; Chowdhury et al., 2015; Grilli et al.,2018; Stenholm et al., 2013; Yay et al., 2018). Moreover, not only national institutional environment but also regional institutional environment significantly determines entrepreneurial activities (Šebestová et al., 2018). Another strand of literature has shed light on the relationship of business risks and entrepreneurship (Acar \& Göç, 2011; Çera et al., 2019a; Jenkins \& McKelvie, 2016; Acar \& Göç, 2011; Çera et al., 2019b; Jenkins \& McKelvie, 2016; Valaskova et al., 2018; Karabag, 2019). Access to finance is another factor that affects business activity (Ardic et al., 2012; Bosma et al., 2018; Ključnikov et al., 2017; Yang, 2017). Besides, social changes can be important for entrepreneurship (EscandonBarbosa et al., 2019; Kliestik et al., 2018; Powell \& Rodet, 2012; Walsh \& Winsor, 2019). Life satisfaction of entrepreneurs is important internal driver of entrepreneurial activity (Shoubaki \& Stephan, 2018).

As firm performance influenced by different factors vary from firm to firm, there is a need to shed some light on the association of different factors for different groups of firms. Policymakers cannot apply the "one size fits all" approach to boost entrepreneurship. In this context, this research seeks to explore the linkages of social factors with firm characteristics (firm age and size) for the enterprises operating in Czech Republic and Slovakia. To the authors' best knowledge, this issue has not received enough attention from scholars. This is a justification why the authors pay attention to this issue, offering a better view on this entrepreneurship puzzle.

The rest of the paper is organized as follows. The next section focuses on theoretical background and hypotheses' development. Section two describes data collection technique, variable measurement and the applied statistical methods. Section three presents the applied analyses and the obtained results. Section four covers the discussion of the results, and the final section provides concluding remarks.

\section{Literature review}

The theoretical background of the current study is built on institutional theory (North, 1990). According to this theory, entrepreneurial activity is influenced by factors which originate from outside the organization. These factors are called by North (1990) as institutions, which can enable or constrain entrepreneurship, including the start-up rate and firm growth. The enterprises do not have the power to control or manipulate these institutions (Shepherd et al., 2019; Draskovic et al., 2019). 
Scholars link entrepreneurship (Stenholm et al., 2013) with institutions (Baumol, 1990; North, 1990; Sobel, 2008) by arguing that institutional environment, consisting on regulatory framework, legislation and social norms, creates the proper circumstances for adults to make decisions, which is vital in entrepreneurial cognition (Zajkowski \& Domańska, 2019; Pinho, 2017; Raza et al., 2018; Sobel, 2008). As Douhan and Henrekson (2010) claim, institutional environment possess the power to determines whether an activity is productive, unproductive or destructive. This lead to the fact that business activity is affected by institutions (Draskovic et al., 2017). Changes in institutions affect the environment where enterprises take and implemented their decisions (Chowdhury et al., 2019; Bilan et al., 2017a).

According to North (1990), institutions can be divided into formal and informal institutions. Formal institutions are written rules communicated via official channels and consist of the complexity and enforcement of the regulations in a country. These rules do not take many years to change since they are not deeply rooted in society. Alongside with formal institutions, informal ones such as social norms are important for entrepreneurship, especially for start-ups (Dvorský et al., 2019a; Fuentelsaz edt al., 2019; Muralidharan \& Pathak, 2017; Welter \& Smallbone, 2011). A different grouping of the institutions is introduced by Williamson (2000). According to the latter study, institutions can be grouped into four levels. The first one consists of informal institutions (such as social norms), which are deeply embedded in society and take many years to change them.

Both media and family environments can motivate adults to get actions towards startup activities (Brixiová \& Égert, 2012; Crammond et al., 2018; Park et al., 2017; Sheng \& Lan, 2019). Low levels of the social environment can reduce investment attractiveness of regions (Viturka et al., 2013). Thus, once more, the social environment is important for entrepreneurial activity (Dvorský et al., 2019b). According to Escandon-Barbosa et al. (2019), social capital positively influences entrepreneurial activity. This result was found to be significant for both developing and developed countries. The latter study measured social capital as Sarracino and Mikucka did (2017), a combination of trust in others, participation in groups or associations, civic cooperation, confidence in public services, confidence in political institutions, confidence in armed forces and police, and confidence in empowering institutions.

The business environment as perceived by enterprises varies across countries (Abdesselam et al., 2018; Ayyagari et al., 2007; Bartelsman et al., 2010; Dilli et al., 2018). Accordingly, the influence of social factors on entrepreneurship is perceived by firms differently across regions and countries (Pinho, 2017; Zygmunt, 2018; Androniceanu, 2019; Pinho, 2017). This is because firms operating in different countries face different social factors in their operations. In this context some authors emphasize the personality of managers and their competencies (Königová et al., 2012; Bilan et al., 2017b; Afonina, 2015).

Social and cultural effect on entrepreneurship differs among countries (Powell \& Rodet, 2012). A study compared the effect of social, cultural and economic factors on entrepreneurship in two different contexts: European, and American and Caribbean countries (Castaño et al., 2015). The latter study found that in both countries, these factors are significant, but the size of the effect differs. Thus, these effects resulted higher in the context of European countries. In this line, it can be argued that the social effect on entrepreneurship is perceived differently among countries (Androniceanu et al., 2019). Based on this logic, a hypothesis can be proposed:

H1: There is a difference in social factors which shape entrepreneurship between countries.

Scholars have demonstrated a negative association between firm age and firm growth. In this context, Xheneti and Bartlett (2012) found a negative impact of firm age and firm 
growth measured as employment growth. Similar results were found even by Hashi and Krasniqi (2011), which showed that firm growth measured as sales growth, is affected by the number of years a firm operates. Also, another study found significant linkages between firm age and critical success factors (including socio-economic issues) for innovative entrepreneurial support (Pansiri \& Temtime, 2010). Moreover, these results are supported by a later study (Gagoitseope \& Pansiri, 2012). Influenced by the above discussion, the following hypotheses can be formulated:

H2a: Social factors which shape entrepreneurship are affected by firm age.

H2b: There is a descending trend across the categories of firm age in social factors.

The size of an enterprise is found to be a significant predictor of business obstacles and firm growth (Ayyagari et al., 2007; Beck et al., 2005). Furthermore, the latter study demonstrated that, compared to medium and large firms, being a small-size firm significantly influence financing, legal and corruption obstacles. This supports the idea that larger firms can be more independent of business constraints. However, some studies found firm size as an insignificant factor of entrepreneurship, in particular, firm growth (Hashi \& Krasniqi, 2011; Xheneti \& Bartlett, 2012). On the other hand, a study found that technological and regulatory changes, seen as part of critical success factors for innovative entrepreneurial support, are linked to firm size (Pansiri \& Temtime, 2010). In this line, larger firms pay more attention to external factors than their smaller counterparts. Similarly, Belás and Sopková (2016) found that Czech small enterprises reflected a lower index of entrepreneurial orientation (innovativeness, pro-active and autonomy) than their larger counterparts. Based on the above discussion, two hypotheses can be formulated:

H3a: Social factors shaping entrepreneurship are affected by firm size.

H3b: There is an ascending trend across the categories of firm size in social factors shaping entrepreneurship.

\section{Methods and procedures}

\section{Aim and data collection}

The aim of this paper is to investigate whether social factors are affected by firm characteristics (firm age and size) or not. The analysis is done on a firm-level data collection through a survey administrated in 2018. The unit of the analysis in this study are SMEs operating in Slovakia and the Czech Republic. To select the respondents, random sample technique was applied in two public databases ("Cribis" and "Albertina" for enterprises operating in Slovakia and the Czech Republic, respectively). The final sample consists of 641 SMEs, where $51 \%$ were from Slovakia. As with previous studies (Çera, Breckova, Çera, \& Rozsa, 2019; Jolley, Lancaster, \& Gao, 2015), the respondent to the survey was either the owner, manager or an individual from the enterprise's top management. As Mallett et al. (2018, p. 16) discussed in their research, "studies that survey owner-manager perceptions will capture some insights into identification-interpretation processes." By doing so, the authors try to further explore the linkages between social factors affecting the entrepreneurial activity and firm characteristics.

\section{Variable measurement}

Both firm age and size were measured as ordinal variables. Hence, respondents were asked to report the number of years of their firm operating in the market $(1=$ 'less than 5 years'; 2 = 'from 5 to 10 years'; 3 = 'more than 10 years') and the firm size ( $1=$ 'micro, $1-9$ employees'; 2 = 'small, 10 - 50 employees'; 3 = 'medium, 51 - 250 employees').

Social factors were measured using the four scales which are: entrepreneurs' views and evaluation of the social environment; family environment; media and communication 
environment; entrepreneurs' social stance. Each scale had four statements (items) formulated as five-point Likert type scale: $1=$ 'totally disagree' to $5=$ 'totally agree'. Their mean and standard deviation are shown in Table 1.

Table 1. Descriptive statistics

\begin{tabular}{|c|c|c|c|}
\hline Code & Description & Mean & SD \\
\hline soc1 & Our society appreciates entrepreneurs & 2.50 & 1.11 \\
\hline $\operatorname{soc} 2$ & $\begin{array}{l}\text { Politicians and the public correctly understand how entrepreneurs contribute to } \\
\text { society }\end{array}$ & 2.20 & 0.93 \\
\hline $\operatorname{soc} 3$ & $\begin{array}{l}\text { My close environment (family, friends, acquaintances) supports me in doing } \\
\text { business }\end{array}$ & 3.98 & 0.80 \\
\hline $\operatorname{soc} 4$ & Good business practices help shape the quality of the business environment & 3.49 & 0.85 \\
\hline famil1 & The family environment motivates people to start a business & 3.46 & 1.02 \\
\hline famil2 & It is easier to do business if close relatives are in business & 3.68 & 0.93 \\
\hline famil3 & I acquired many skills in my family that help me in my bus & 3.55 & 1.02 \\
\hline famil4 & My family helps me in my business & 3.91 & 0.82 \\
\hline media1 & $\begin{array}{l}\text { Media (television, broadcast, and other media) truthfully inform about } \\
\text { entrepreneurship }\end{array}$ & 2.52 & 1.00 \\
\hline media2 & $\begin{array}{l}\text { Media help shape the quality of business environment using presentations of } \\
\text { goof business practices }\end{array}$ & 2.79 & 0.96 \\
\hline media3 & Media adequately inform about the business environment & 2.85 & 0.97 \\
\hline media4 & Media support entrepreneurs' communication with the public & 2.90 & 0.95 \\
\hline ent_adv1 & The advantages of doing business outnumber the disadvantag & 3.23 & 1.05 \\
\hline ent_adv2 & An entrepreneur is wealthier and has a higher social status & 2.85 & 1.06 \\
\hline ent_adv3 & $\begin{array}{l}\text { Entrepreneurship enables better career growth and leads to interesting work } \\
\text { opportunities }\end{array}$ & 3.61 & 0.90 \\
\hline $\mathrm{v} 4$ & Conducting business allows for full utilization of one's skills & 4.04 & 0.81 \\
\hline
\end{tabular}

Note: The source of the statements is Cepel et al. (2018). SD is the standard deviation.

\section{Methods and effect size}

Since the current research seeks to check whether firm characteristics (firm age and size) affect social factors or not, a one-way between-subjects analysis of variance (ANOVA) can be employed. However, the assumptions of ANOVA were not satisfied, which leads to the use of the Kruskal-Wallis test (Gravetter \& Wallnau, 2017). The latter test allows scholars the opportunity to compare the scores a continuous variable for three or more groups. The mean rank for each group is compared after these scores are transformed into ranks (Pallant, 2016).

Furthermore, the comparison of the categories of firm characteristics (firm age and size) offer a meaningful order of medians. To test for trends in social factors categories (ordinal variable), the Jonckheere-Terpstra test was applied. In the case of large sample size, this test has a normal distribution, indicating that $z$ score can be calculated and further interpreted. A positive $z$ score indicates a trend of ascending medians (Field, 2009). The effect size of the test can be calculated as the division of $z$ score with the square root of sample size. To judge this effect size, Cohen's (1988) benchmarks were considered: 0.01=small, $0.30=$ medium and $0.50=$ large effect.

To test for differences between firm characteristics categories (in pair) in social factors, Mann-Whitney test was performed. The assumptions of applying t-test were violated, which indicate the use of the Mann-Whitney test. Compared to the Kruskal-Wallis test, Mann-Whitney test analysis the difference only between two groups. The strength of the 
effect can be calculated and interpreted similarly with the case of the Jonckheere-Terpstra test. The three tests abovementioned are among nonparametric methods (Hollander et al., 2013).

\section{Analysis and results}

\section{Factor analysis}

As mentioned earlier, sixteen indicators were designed and used to capture social influence over entrepreneurial activity. To reduce the huge number of variables, in the current research, factor analysis was employed (Fabrigar \& Wegener, 2011). The principal component analysis helped summarise entrepreneurs' perceptions of sixteen statements into a smaller number of latent variables or underlying factors. Only factors with eigenvalues higher than one were kept. Four factors emerge from the performed factor analysis, which explained $59.31 \%$ of the variance in the sample. The Kaiser-Meyer-Olkin value was greater than the threshold of 0.70 and Barlett's test of sphericity was significant (Hair et al., 2010), provide evidence of the appropriateness of factor analysis. Nevertheless, indicators such as famill, famil 2 and soc4, showed low communality and loading values signalling their removal from the analysis. The final rotated component matrix is reported in Table 2. All factor loadings were well in excess of Stevens (2015) benchmark of 0.40, providing evidence of constructs convergent validity.

Table 2. Rotated component matrix

\begin{tabular}{|c|c|c|c|c|c|}
\hline \multirow[b]{2}{*}{ Items } & \multicolumn{4}{|c|}{ Loadings } & \multirow{2}{*}{ Communalities } \\
\hline & Factor 1 & Factor 2 & Factor 3 & Factor 4 & \\
\hline media3 & 0.815 & & & & 0.711 \\
\hline media4 & 0.779 & & & & 0.654 \\
\hline media1 & 0.700 & & & & 0.658 \\
\hline media2 & 0.682 & & & & 0.593 \\
\hline famil4 & & 0.799 & & & 0.659 \\
\hline $\operatorname{soc} 3$ & & 0.776 & & & 0.552 \\
\hline famil3 & & 0.752 & & & 0.509 \\
\hline ent_adv3 & & & 0.748 & & 0.675 \\
\hline ent_adv4 & & & 0.646 & & 0.629 \\
\hline ent_adv2 & & & 0.594 & & 0.436 \\
\hline ent_adv1 & & & 0.594 & & 0.593 \\
\hline soc1 & & & & 0.818 & 0.471 \\
\hline $\operatorname{soc} 2$ & & & & 0.756 & 0.570 \\
\hline Eigenvalues & 3.225 & 2.102 & 1.288 & 1.094 & \\
\hline$\%$ of variance $($ total $=59.31 \%)$ & 18.31 & 14.99 & 14.07 & 11.93 & \\
\hline
\end{tabular}

Note: Extraction: Principal Component Analysis; Rotation: Varimax with Kaiser Normalization; Kaiser-MeyerOlkin Measure of sampling adequacy $=0.782$. Sig. Bartlett's test $<0.001$. Correlation matrix's determinant $=$ 0.068 ; Rotation converged in 5 iterations. Coefficient loading displayed $>|0.5|$.

The first factor combines items related to media and communication environment and explains $18.31 \%$ of the variance in the sample. The second factor combines three items about the family environment. One item (soc3) was expected to load into the last extracted factor. A careful look at that item description ('My close environment (family, friends, acquaintances) supports me in doing business'), lead to the fact that it can be grouped as an indicator of the family environment factor. This was the reason why it was not deleted from the analysis. The 
third factor combines responses about the image entrepreneurs are preserved from the society. The fourth factor is a combination of two items pointing social environment. According to Fabrigar and Wegener's (2011) suggestion, when there are only two substantial loadings on some factors, sample sizes of 400 or greater may be needed. The sample size of the current research if well above this threshold. These factors were generated to follow-up the analysis in the way to test the proposed hypotheses.

To examine differences in the social factors between the two countries, an independent t-test can be executed. However, this test requires that the variables should be normally distributed (Pallant, 2016). If this assumption is violated, then a non-parametric test such as the Mann-Whitney test should run. To check whether this assumption is violated or not, Kolmogorov-Smirnov and Shapiro-Wilk test in SPSS 23 were performed along with the normal probability (or Q-Q) plots (Meyers, Gamst, \& Guarion, 2013), and their results are shown in Table 3. Both tests revealed that the extracted factors were not normally distributed, indicating the use of the Mann-Whitney test instead of independent t-test.

Table 3. Tests of normality

\begin{tabular}{lcccccc}
\hline & \multicolumn{3}{c}{ Kolmogorov-Smirnov $^{\mathrm{a}}$} & \multicolumn{3}{c}{ Shapiro-Wilk } \\
\hline Statistic & $\mathrm{df}$ & $p$ & Statistic & $\mathrm{df}$ & $p$ \\
\hline Factor 1 & 0.049 & 641 & 0.001 & 0.992 & 641 & 0.001 \\
\hline Factor 2 & 0.059 & 641 & 0.000 & 0.973 & 641 & 0.000 \\
\hline Factor 3 & 0.054 & 641 & 0.000 & 0.984 & 641 & 0.000 \\
\hline Nor & 0.063 & 641 & 0.000 & 0.977 & 641 & 0.000 \\
\hline
\end{tabular}

Note: a. Lilliefors significance correction.

\section{Testing for differences and linkages}

To test hypothesis H1, Mann-Whitney test was performed. It appeared that, excluding Factor $2(U=49739, z=-0.676, p=0.499, r=0.027)$, when comparing two countries, businesses perceived social factors statistically different (see Table 4). Moreover, a careful examination of the mean ranks leads to the clarification of the difference direction. In comparison with firms operating in the Czech Republic, those in Slovakia scored higher in Factor $1(U=44257, z=-3.016, p<0.01, r=0.119)$, Factor $3(U=45790, z=-2.361, p<$ $0.05, r=0.093)$ and Factor $4(U=45451, z=-2.506, p<0.05, r=0.099)$. The strength of the effect resulted small to medium. Thus, excluding Factor 2 which deals with family environment, the other social factors support $\mathrm{H} 1$.

Table 4. Results of Mann-Whitney test: differences between the two countries

\begin{tabular}{lcccccc}
\hline & \multicolumn{2}{c}{ Mean rank } & \multicolumn{3}{c}{ Mann-Whitney } \\
\hline & Czech Republic $(n=312)$ & Slovakia $(n=329)$ & $U$ & $z$ & $p$ & $r$ \\
\hline Factor 1 & 298.35 & 342.48 & 44257 & -3.016 & 0.003 & 0.119 \\
\hline Factor 2 & 315.92 & 325.82 & 49739 & -0.676 & 0.499 & 0.027 \\
\hline Factor 3 & 303.26 & 337.82 & 45790 & -2.361 & 0.018 & 0.093 \\
\hline Factor 4 & 302.18 & 338.85 & 45451 & -2.506 & 0.012 & 0.099 \\
\hline
\end{tabular}

$\mathrm{H} 2 \mathrm{a}$ claims that there is an association between social factors and firm age. In the current research, this can be investigated by employing the Kruskal-Wallis test. The results of this test are presented in Table 5. Only two out of four social factors resulted to be statistically significant different across firm age categories, which are Factor $1(H(2, n=641)=8.980, p<$ 
$.05)$ and Factor $4(H(2, n=641)=6.909, p<.05)$. Since only two factors were statistically significant, therefore, $\mathrm{H} 2 \mathrm{a}$ was partly supported.

To test whether is the trend across the firm age categories in the social factors a descending or not, Jonckheere-Terpstra test was conducted. It appeared a statistical significance descending trend in the data in cases of Factor $1(J=53840, z=-2.880, p<0.01$, $r=0.114)$ and Factor $4(J=54508, z=-2.606, p<0.01, r=0.103)$. The effect sizes were small to medium (see Table 5). Hence, as young, the firms were, the higher was their perception of social factors. Thus, concerning Factor 1 and Factor 4, the evidence supported $\mathrm{H} 2 \mathrm{~b}$. Taking all together, H2b was partly supported, since two other social factors showed no trend across firm age categories.

Table 5. Results of Kruskal-Wallis and Jonckheere-Terpstra tests for firm age

\begin{tabular}{|c|c|c|c|c|c|c|c|c|c|}
\hline & \multirow[b]{2}{*}{ Firm age } & \multirow[b]{2}{*}{$\mathrm{N}$} & \multirow{2}{*}{$\begin{array}{l}\text { Mean } \\
\text { rank }\end{array}$} & \multicolumn{2}{|c|}{ Kruskal-Wallis } & \multicolumn{4}{|c|}{ Jonckheere-Terpstra } \\
\hline & & & & $H(2)$ & $p$ & $J$ & $z$ & $p$ & $r$ \\
\hline \multirow[t]{3}{*}{ Factor 1} & Less than 5 years & 160 & 345.58 & 8.980 & 0.011 & 53840 & -2.880 & 0.004 & 0.114 \\
\hline & From 5 to 10 years & 126 & 345.21 & & & & & & \\
\hline & More than 10 years & 355 & 301.33 & & & & & & \\
\hline \multirow[t]{3}{*}{ Factor 2} & Less than 5 years & 160 & 327.66 & 0.302 & 0.860 & 59962 & -0.363 & 0.717 & 0.014 \\
\hline & From 5 to 10 years & 126 & 316.48 & & & & & & \\
\hline & More than 10 years & 355 & 319.60 & & & & & & \\
\hline \multirow[t]{3}{*}{ Factor 3} & Less than 5 years & 160 & 325.89 & 0.154 & 0.926 & 60225 & -0.255 & 0.799 & 0.010 \\
\hline & From 5 to 10 years & 126 & 318.34 & & & & & & \\
\hline & More than 10 years & 355 & 319.74 & & & & & & \\
\hline \multirow[t]{3}{*}{ Factor 4} & Less than 5 years & 160 & 344.81 & 6.909 & 0.032 & 54508 & -2.606 & 0.009 & 0.103 \\
\hline & From 5 to 10 years & 126 & 339.16 & & & & & & \\
\hline & More than 10 years & 355 & 303.83 & & & & & & \\
\hline
\end{tabular}

The findings provided by the Kruskal-Wallis test need a pos-thoc test to investigate in which pair of firm age categories is present the difference of social factors. For this reason, the Mann-Whitney test was run, and its results are shown in Table 6. According to it, firms with more than 10 years of operation in the market scored significantly lower on Factor 1 , when compared with those with less than 5 years $(U=24488, z=-2.503, p<0.05, r=0.110)$ and from 5 to 10 years $(U=19293, z=-2.292, p<0.05, r=0.105)$. The same results were taken even for Factor 4. Thus, firms with less than 5 years $(U=24831, z=-2.284, p<0.05, r$ $=0.101)$ and from 5 to 10 years of experience $(U=19837, z=-1.886, p<0.10, r=0.086)$, scored higher in Factor 1 and Factor 4.

Table 6. Results of the post-hoc Mann-Whitney test for firm age

\begin{tabular}{cccccccc}
\hline & & Mean ranks & & \multicolumn{3}{c}{ Mann-Whitney } \\
\hline & Less than 5 years & From 5 to 10 years & More than 10 years & $\mathrm{U}$ & $z$ & $p$ & $r$ \\
\hline Factor 1 & 143.63 & 143.33 & - & 10059 & -0.030 & 0.976 & 0.002 \\
\hline & 282.45 & - & 246.98 & 24488 & -2.503 & 0.012 & 0.110 \\
\hline Factor 4 & - & 265.38 & 232.35 & 19293 & -2.292 & 0.022 & 0.105 \\
\hline & 145 & 141.6 & - & 9840 & -0.346 & 0.730 & 0.020 \\
\hline & 280.31 & - & 247.95 & 24831 & -2.284 & 0.022 & 0.101 \\
\hline
\end{tabular}


One of the developed hypothesis in the current research proposed that social factors are affected by firm size (H3a). To test this hypothesis, the Kruskal-Wallis test was performed. The results of this test are shown in Table 7. Three social factors were found to be statistically significant different across firm size categories, which are Factor $2(H(2, n=641)$ $=5.652, p<.10)$, Factor $3(H(2, n=641)=12.77, p<.01)$ and Factor $4(H(2, n=641)=$ 15.967, $p<.001$ ). Therefore, H3a was supported, but not fully since the association between Factor 1 and firm size was reported insignificant.

To explore whether is the trend across the firm size categories in the social factors an ascending or not, Jonckheere-Terpstra test was employed. Its results showed a statistical significance ascending trend in the data in cases of Factor $2(J=42979.5, z=2.173, p<0.05$, $r=0.086)$, Factor $3(J=43873.5, z=2.621, p<0.01, r=0.104)$ and Factor $4(J=44238.5, z$ $=2.805, p<0.01, r=0.111$ ). The strength of the effects was small to medium (see table 7). Hence, as big the firm was, the higher was its perception in social factors. Thus, concerning Factor 2, Factor 3 and Factor 4, the evidence supported H3b. However, since Factor 1 did not refract any trend across firm size categories, H3b was partly supported.

Table 7. Kruskal-Wallis and Jonckheere-Terpstra tests for firm size

\begin{tabular}{lccccccccc}
\hline & \multicolumn{3}{c}{ Mean rank } & \multicolumn{4}{c}{ Kruskal-Wallis } & \multicolumn{3}{c}{ Jonckheere-Terpstra } \\
\hline & Micro $(n=492)$ & Small $(n=114)$ & Medium $(n=35)$ & $H(2)$ & $p$ & $J$ & $z$ & $p$ & $r$ \\
\hline Factor 1 & 318.59 & 341.81 & 287.11 & 2.695 & 0.260 & 39529 & 0.442 & 0.659 & 0.017 \\
\hline Factor 2 & 312.68 & 338.63 & 380.60 & 5.652 & 0.059 & 42979 & 2.173 & 0.030 & 0.086 \\
\hline Factor 3 & 309.49 & 377.02 & 300.31 & 12.77 & 0.002 & 43873 & 2.621 & 0.009 & 0.104 \\
\hline Factor 4 & 310.86 & 328.43 & 439.40 & 15.97 & 0.000 & 44238 & 2.805 & 0.005 & 0.111 \\
\hline
\end{tabular}

Although it was obtained statistically significant results from the Kruskal-Wallis test, yet is not clear which of the groups are statistically significantly different from one another. To find this out, some follow-up Mann-Whitney tests between pairs of groups were done. Interesting results are found (see Table 8). In comparison with micro-sized firms, the medium ones scored significantly higher in Factor $2(U=6759, z=-2.126, p<0.05, r=0.093)$ and Factor $4(U=5065, z=-4.073, p<0.001, r=0.177)$. Similarly, when compared to smallsized firms, the medium ones scored significantly higher in Factor $3(U=1557, z=-1.961, p$ $<0.05, r=0.161)$ and Factor $4(U=1396, z=-2.682, p<0.01, r=0.220)$. Compared to micro-sized firms, the small ones scored higher only in Factor $3(U=22096, z=-3.532, p<$ $0.001, r=0.143)$.

Table 8. Results of the post-hoc Mann-Whitney test for firm size

\begin{tabular}{cccccccc}
\hline & \multicolumn{3}{c}{ Mean rank } & \multicolumn{4}{c}{ Mann-Whitney } \\
\hline Factor 2 & Micro & Small & Medium & $U$ & $z$ & $p$ & $r$ \\
\hline & 298.94 & 323.19 & - & 25800 & -1.333 & 0.183 & 0.054 \\
\hline Factor 3 & 260.24 & - & 316.89 & 6759 & -2.126 & 0.033 & 0.093 \\
\hline & - & 72.94 & 81.71 & 1760 & -1.052 & 0.293 & 0.086 \\
\hline Factor 4 & 291.41 & 355.68 & - & 22096 & -3.532 & 0.000 & 0.143 \\
\hline & 264.58 & - & 255.83 & 8324 & -0.329 & 0.742 & 0.014 \\
\hline & - & 78.84 & 62.49 & 1557 & -1.961 & 0.050 & 0.161 \\
\hline & 256.56 & 316.18 & - & 26599 & -0.858 & 0.391 & 0.035 \\
\hline & - & 69.75 & 92.11 & 1396 & -2.682 & 0.007 & 0.220 \\
\hline
\end{tabular}




\section{Discussion}

The current research has shown insight results regarding the links between social factors which shape entrepreneurial activity and firm characteristics (firm size and age). The data showed that these factors do significantly associate with firm characteristics. Moreover, they differ between the two countries (the Czech Republic and Slovakia). However, these results should be discussed a bit more carefully.

To follow methodological rigour procedures, initially, numerous indicators covering four different aspects of the social environment (entrepreneurs' views and evaluation of the social environment; family environment; media and communication environment; entrepreneurs' social stance) were grouped using factor analysis with Varimax rotation. Next, the emerged factors were teste whether they associate with firm characteristics or not employing three non-parametric methods. These steps were followed to explore whether the research hypotheses are supported by our data or not.

The first hypothesis of the current study claims that social factors with shape entrepreneurship vary across countries. The employed test showed that this is true for three out of four social factors. Moreover, the data demonstrated that Slovak firms scored significantly higher on social factors, in comparison with Czech counterparts. Even though these two countries share quite similar cultural heritage and economic development level, the evidence revealed differences in entrepreneurs' perception of the influence of social factors in entrepreneurial activity. Our results are consistent with prior research in the field of entrepreneurship, which have argued that social factors vary across countries (Ayyagari et al., 2007; Castaño et al., 2015; Dilli et al., 2018).

The second block of hypotheses ( $\mathrm{H} 2 \mathrm{a}$ and $\mathrm{H} 2 \mathrm{~b}$ ) links social factors which shape entrepreneurship and firm age. Two out of four factors showed a statistically significant association with firm age. Furthermore, as the age of firms increases, the lower was the entrepreneurs' perception of social factors as important for entrepreneurship. Thus, younger firms perceived higher the role of social factors on entrepreneurial activity, as compared with older counterparts. These findings are in line with previous studies (Gagoitseope \& Pansiri, 2012; Hashi \& Krasniqi, 2011; Pansiri \& Temtime, 2010; Xheneti \& Bartlett, 2012).

To investigate whether social factors, which influence entrepreneurial activity, are affected by firm size, two non-parametric tests were used followed-up with a post-hoc test. Analyses revealed that social factors, (excluding one factor emerged from factor analysis) are statistically affected by firm size, supporting H3a. In addition, substantial evidence supported the hypothesis ( $\mathrm{H} 3 \mathrm{~b})$, which claims it is an ascending trend across the categories of firm size in social factors which influence entrepreneurship. Hence, the smaller the firms, the lower the scores on social factors. These findings converge with prior studies (Beck et al., 2005; Pansiri \& Temtime, 2010), and contradicts with some others (Hashi \& Krasniqi, 2011; Xheneti \& Bartlett, 2012).

\section{Conclusion}

Considering social and economic benefits of business activity, academicians, government and public-policy advocates have an interest in understanding the linkages between firm characteristics with perceived important factors for entrepreneurial activity. In this way, the above actors can adjust existing policies aiming at entrepreneurship. Accordingly, it is important to investigate psychological, situational and contextual factors that shape entrepreneurial activity (Ayyagari et al., 2007; Çera, et al., 2019b; Chowdhury et al., 2019). 
The current research made an effort to investigate whether firm characteristics are linked to perceived important social factors for the entrepreneurial activity or not in the context of two countries from Central Europe (Slovakia and Czech Republic). Although factors that influence entrepreneurship are numerous and complex, informal institutions (including social norms and culture) play an important role in this regard (Aparicio et al., 2016; North, 1990; Siqueira et al., 2016). This study identified four social factors related to the business environment: media and communication environment; family environment; entrepreneurs' social stance, and social environment. Next step was the investigation of the possible linkages between social factors and firm characteristics.

Evidence supports the idea that social factors which shape entrepreneurship vary between countries and firm characteristics, indicating that a "one size fits all" approach cannot work in adjusting or designing business enabling policies (Beck et al., 2005; Pansiri \& Temtime, 2010). Therefore, there is a constant interest to explore and understand in which group of firms should be applied a certain policy aiming their enhancement. Slovak firms, excluding the factor dealing with a family environment, perceived these social factors higher than their Czech counterparts. In comparison to older firms, younger ones perceived higher media and social environments. It seems that younger firms are more vulnerable to these factors. On the other hand, the larger the size of the firm, the higher the perception of social and family environment, and entrepreneurs' social stance.

Even though the aim of the study was achieved, there are limitations to the research. Although rigour methodological approaches were applied, more studies are needed to investigate in depth the relationships between firm characteristics and factors that influence the business environment. Another limitation is that four factors could not cover all aspects of the social environment. The latter limitation can be overcome by doing more research in this regard.

\section{Acknowledgement}

This paper was supported by the Internal Grant Agency of Faculty of Management and Economics, Tomas Bata University, no. IGA/FaME/2019/002: The role of institutional environment in fostering entrepreneurship.

\section{References}

Abdesselam, R., Bonnet, J., Renou-Maissant, P., \& Aubry, M. (2018). Entrepreneurship, economic development, and institutional environment: evidence from OECD countries. Journal of International Entrepreneurship, 16(4), 504-546.

Acar, E., \& Göç, Y. (2011). Prediction of risk perception by owners' psychological traits in small building contractors. Construction Management and Economics, 29(8), 841-852.

Acs, Z. J., Estrin, S., Mickiewicz, T., \& Szerb, L. (2018). Entrepreneurship, institutional economics, and economic growth: an ecosystem perspective. Small Business Economics, $51(2), 501-514$.

Afonina, A. (2015). Strategic Management Tools and Techniques and Organizational Performance: Findings from the Czech Republic. Journal of Competitiveness, Vol. 7, Issue 3, pp. 19-36.

Androniceanu, A. (2019). Social responsibility, an essential strategic option for a sustainable development in the field of bio-economy, Amfiteatru Economic, 21(52), 503-519.

Androniceanu, A., Gherghina, R., Ciobanasu, M. (2019). The interdependence between fiscal public policies and tax evasion, Administratie si Management Public, (32), 32-41. 
Aparicio, S., Urbano, D., \& Audretsch, D. (2016). Institutional factors, opportunity entrepreneurship and economic growth: Panel data evidence. Technological Forecasting and Social Change, 102, 45-61.

Ardic, O. P., Mylenko, N., \& Saltane, V. (2012). Access to Finance by Small and Medium Enterprises: a Cross-Country Analysis with A New Data Set. Pacific Economic Review, 17(4), 491-513.

Ayyagari, M., Beck, T., \& Demirguc-Kunt, A. (2007). Small and Medium Enterprises Across the Globe. Small Business Economics, 29(4), 415-434.

Bartelsman, E., Haltiwanger, J., \& Scarpetta, S. (2010). Cross-country and within-country differences in the business climate. International Journal of Industrial Organization, $28(4), 368-371$.

Baumol, W. J. (1990). Entrepreneurship: Productive, Unproductive, and Destructive. Journal of Political Economy, 98(5, Part 1), 893-921.

Beck, T., Demirgüç-Kunt, A., \& Maksimovic, V. (2005). Financial and legal constraints to growth: Does firm size matter? Journal of Finance, Vol. 60, pp. 137-177.

Belás, J., \& Sopková, G. (2016). A Model of Entrepreneurial Orientation. Transformation in Business \& Economics, 15(2), 630-644.

Bjørnskov, C., \& Foss, N. J. (2016). Institutions, Entrepreneurship, and Economic Growth: What Do We Know and What Do We Still Need to Know? Academy of Management Perspectives, 30(3), 292-315.

Bilan, Y., Gavurova, B., Stanisław, G., \& Tkacova, A. (2017a). The Composite Coincident Indicator (CCI) for Business Cycles. Acta Polytechnica Hungarica, 14(7), 71-90.

Bilan, Y., Mishchuk, H., \& Dzhyhar, T. (2017b). Human capital factors and remuneration: analysis of relations, modelling of influence. Business: Theory and Practice, 18, 208-214

Bosma, N., Content, J., Sanders, M., \& Stam, E. (2018). Institutions, entrepreneurship, and economic growth in Europe. Small Business Economics, 51(2), 483-499.

Bowen, H. P., \& De Clercq, D. (2008). Institutional context and the allocation of entrepreneurial effort. Journal of International Business Studies, 39(4), 747-767.

Brixiová, Z., \& Égert, B. (2012). Business environment, start-ups, and productivity during transition. Macroeconomic Dynamics, 16(S2), 213-231.

Castaño, M.-S., Méndez, M.-T., \& Galindo, M.-Á. (2015). The effect of social, cultural, and economic factors on entrepreneurship. Journal of Business Research, 68(7), 1496-1500.

Çera, G., Belás, J., \& Strnad, Z. (2019a). Important factors which predict entrepreneur's perception in business risk. Problems and Perspectives in Management, 17(2), 415-429.

Çera, G., Breckova, P., Çera, E., \& Rozsa, Z. (2019b). The Effect of Business Enabling Policies, Tax Treatment, Corruption and Political Connections on Business Climate. Acta Polytechnica Hungarica, 16(4), 113-132.

Chowdhury, F., Audretsch, D. B., \& Belitski, M. (2019). Institutions and Entrepreneurship Quality. Entrepreneurship Theory and Practice, 43(1), 51-81.

Chowdhury, F., Terjesen, S., \& Audretsch, D. (2015). Varieties of entrepreneurship: institutional drivers across entrepreneurial activity and country. European Journal of Law and Economics, 40(1), 121-148.

Cohen, J. (1988). Statistical power analysis for the behavioral sciences (2nd ed.). United States of America: L. Erlbaum Associates.

Crammond, R., Omeihe, K. O., Murray, A., \& Ledger, K. (2018). Managing knowledge through social media. Baltic Journal of Management, 13(3), 303-328.

Dilli, S., Elert, N., \& Herrmann, A. M. (2018). Varieties of entrepreneurship: exploring the institutional foundations of different entrepreneurship types through 'Varieties-ofCapitalism' arguments. Small Business Economics, 51(2), 293-320.

Douhan, R., \& Henrekson, M. (2010). Entrepreneurship and second-best institutions: going 
beyond Baumol's typology. Journal of Evolutionary Economics, 20(4), 629-643.

Draskovic, V., Popov, E., \& Peleckis, K.K. (2017). Modelling of Institutional Changes in Transition Countries - the Gap Between the Theory and Practice. Montenegrin Journal of Economics, Vol. 13, No. 1, 125-140.

Draskovic, V., Draskovic, M., \& Bilan, S. (2019). Motivation, Methodology, and Phenomenology of Institutional Nihilism in the SEE Countries. Montenegrin Journal of Economics, 15(2),7-14.

Dvorský, J., Petráková, Z., Çera, G., \& Folvarčna, A. (2019). Important factors for the entrepreneurship in Central Europe. Innovative Marketing, 15(2), 71-83.

Dvorský, J., Petráková, Z., Zapletalíková, E., \& Rózsa, Z. (2019b). Entrepreneurial propensity index of university students. The case study from the Czech Republic, Slovakia and Poland. Oeconomia Copernicana, 10(1), 173-192.

Escandon-Barbosa, D., Urbano-Pulido, D., \& Hurtado-Ayala, A. (2019). Exploring the relationship between formal and informal institutions, social capital, and entrepreneurial activity in developing and developed countries. Sustainability (Switzerland), 11(2).

European Commission. (2018). 2018 SBA Fact Sheet. Retrieved from Small Business Directive, Late Payment Small, The Act, Business website: http://ec.europa.eu/growth/smes/business-friendly-environment/performance-review/

Fabrigar, L. R., \& Wegener, D. T. (2011). Exploratory Factor Analysis. New York, NY: Oxford University Press.

Field, A. (2009). Discovering statistics using SPSS (3rd ed.). London: SAGE.

Fuentelsaz, L., González, C., \& Maicas, J. P. (2019). Formal institutions and opportunity entrepreneurship. The contingent role of informal institutions. BRQ Business Research Quarterly, 22(1), 5-24.

Gagoitseope, P. K., \& Pansiri, J. (2012). Evaluation of critical success factors for developing small and medium-sized enterprises in Botswana. Journal of African Business, 13(1), 51-61.

Gravetter, F. J., \& Wallnau, L. B. (2017). Statistics for the behavioral sciences (10th ed.). CENGAGE Learning.

Grilli, L., Mrkajic, B., \& Latifi, G. (2018). Venture capital in Europe: social capital, formal institutions and mediation effects. Small Business Economics, 51(2), 393-410.

Hair, J. F., Black, W. C., Babin, B. J., \& Anderson, R. E. (2010). Multivariate Data Analysis (7th Editio). Harlow: Pearson Education Limited.

Hashi, I., \& Krasniqi, B. A. (2011). Entrepreneurship and SME growth: evidence from advanced and laggard transition economies. International Journal of Entrepreneurial Behavior \& Research, 17(5), 456-487.

Hollander, M., Wolfe, D. A., \& Chicken, E. (2013). Nonparametric statistical methods. (3rd ed.). New Jersey: Wiley.

Jenkins, A., \& McKelvie, A. (2016). What is entrepreneurial failure? Implications for future research. International Small Business Journal: Researching Entrepreneurship, 34(2), $176-188$.

Jolley, G. J., Lancaster, M. F., \& Gao, J. (2015). Tax Incentives and Business Climate: Executive Perceptions From Incented and Nonincented Firms. Economic Development Quarterly, 29(2), 180-186.

Karabag, S. F. (2019). Factors impacting firm failure and technological development: A study of three emerging-economy firms. Journal of Business Research, 98, 462-474.

Kliestik, T., Misankova, M., Valaskova, K., \& Svabova, L. (2018). Bankruptcy Prevention: New Effort to Reflect on Legal and Social Changes. Science and Engineering Ethics, 24(2), 791-803.

Ključnikov, A., Kozubíková, L., \& Sopková, G. (2017). The Payment Discipline of Small and 
Medium-sized Enterprises. Journal of Competitiveness, 9(2), 45-61.

Königová, M., Urbancová, H., \& Fejfar, J. (2012). Identification of Managerial Competencies in Knowledge-based Organizations (2012). Journal of Competitiveness, Vol. 4, Issue 1, pp. 129-142.

Mallett, O., Wapshott, R., \& Vorley, T. (2018). How Do Regulations Affect SMEs? A Review of the Qualitative Evidence and a Research Agenda. International Journal of Management Reviews.

Meyers, L. S., Gamst, G. C., \& Guarion, A. J. (2013). Performing data analysis using IBM SPSS. New Jersey: Wiley.

Muralidharan, E., \& Pathak, S. (2017). Informal institutions and international entrepreneurship. International Business Review, 26(2), 288-302.

North, D. C. (1990). Institutions, institutional change, and economic performance. Cambridge University Press.

Pallant, J. (2016). SPSS survival manual: a step by step guide to data analysis using IBM SPSS (6th ed.). New York, NY: McGraw-Hill Education.

Pansiri, J., \& Temtime, Z. T. (2010). Linking firm and managers' characteristics to perceived critical success factors for innovative entrepreneurial support. Journal of Small Business and Enterprise Development, 17(1), 45-59.

Park, J., Sung, C., Im, I., Park, J. Y., Sung, C. S., \& Im, I. (2017). Does Social Media Use Influence Entrepreneurial Opportunity? A Review of its Moderating Role. Sustainability, 9(9), 1593.

Pinho, J. C. (2017). Institutional theory and global entrepreneurship: exploring differences between factor- versus innovation-driven countries. Journal of International Entrepreneurship, 15(1), 56-84.

Powell, B., \& Rodet, C. (2012). Praise and profits: Cultural and institutional determinants of entrepreneurship. Journal of Private Enterprise, 27(2), 19-42.

Raza, A., Muffatto, M., \& Saeed, S. (2018). The influence of formal institutions on the relationship between entrepreneurial readiness and entrepreneurial behaviour. Journal of Small Business and Enterprise Development, JSBED-01-2018-0014.

Rogalska, E. (2018). Multiple-criteria analysis of regional entrepreneurship conditions in Poland. Equilibrium. Quarterly Journal of Economics and Economic Policy, 13(4), 707723.

Sarracino, F., \& Mikucka, M. (2017). Social Capital in Europe from 1990 to 2012: Trends and Convergence. Social Indicators Research, 131(1), 407-432.

Sheng, J., \& Lan, H. (2019). Business failure and mass media: An analysis of media exposure in the context of delisting event. Journal of Business Research, 97, 316-323.

Shepherd, D. A., Wennberg, K., Suddaby, R., \& Wiklund, J. (2019). What Are We Explaining? A Review and Agenda on Initiating, Engaging, Performing, and Contextualizing Entrepreneurship. Journal of Management, 45(1), 159-196.

El Shoubaki, A., \& Stephan, M. (2018). The Life Partner and the Life Satisfaction of the Entrepreneur. Central European Business Review, 7(3), 26-41. doi: 10.18267/j.cebr.201.

Siqueira, A. C. O., Webb, J. W., \& Bruton, G. D. (2016). Informal Entrepreneurship and Industry Conditions. Entrepreneurship Theory and Practice, 40(1), 177-200.

Sobel, R. S. (2008). Testing Baumol: Institutional quality and the productivity of entrepreneurship. Journal of Business Venturing, 23(6), 641-655.

Stenholm, P., Acs, Z. J. \& Wuebker, R. (2013). Exploring country-level institutional arrangements on the rate and type of entrepreneurial activity. Journal of Business Venturing, 28(1), 176-193.

Stevens, J. P., \& Pituch, K. A. (2015). Applied Multivariate Statistics for the Social Sciences: Analyses with SAS and IBM's SPSS (6th ed.). Routledge. 
Šebestová, J., Krejčí, P., \& Šiška, P. (2018). "Be or Not To Be": A Dilemma of Business Policy Support on a Regional Level. Central European Business Review, 7(1), 3-13. doi: 10.18267/j.cebr.192.

Valaskova, K., Kliestik, T., \& Kovacova, M. (2018). Management of financial risks in Slovak enterprises using regression anaylsis. Oeconomia Copernicana, 9(1), 105-121.

Viturka, M., Wokoun, R., Krejcova, N., Tonev, P., \& Zitek, V. (2013). The regional relationship between quality of business and social environment: harmony or disharmony? E+M Ekonomie a Management, 16(2), 22-40.

Walsh, J., \& Winsor, B. (2019). Socio-cultural barriers to developing a regional entrepreneurial ecosystem. Journal of Enterprising Communities: People and Places in the Global Economy, JEC-11-2018-0088.

Welter, F., \& Smallbone, D. (2011). Institutional Perspectives on Entrepreneurial Behavior in Challenging Environments. Journal of Small Business Management, 49(1), 107-125.

Williamson, O. E. (2000). The New Institutional Economics: Taking Stock, Looking Ahead. Journal of Economic Literature, 38(3), 595-613.

Xheneti, M., \& Bartlett, W. (2012). Institutional constraints and SME growth in post-communist Albania. Journal of Small Business and Enterprise Development, 19(4), $607-626$.

Yang, J. S. (2017). The governance environment and innovative SMEs. Small Business Economics, 48(3), 525-541.

Yay, T., Yay, G. G., \& Aksoy, T. (2018). Impact of institutions on entrepreneurship: a panel data analysis. Eurasian Economic Review, 8(1), 131-160.

Zajkowski, R., \& Domańska, A. (2019). Differences in perception of regional proentrepreneurial policy: does obtaining support change a prospect?. Oeconomia Copernicana, 10(2), 359-384.

Zygmunt, J. (2018). Entrepreneurial activity drivers in the transition economies. Evidence from the Visegrad countries. Equilibrium. Quarterly Journal of Economics and Economic Policy, 13(1), 89-103. 